\title{
Family studies in ornithine transcarbamylase deficiency
}

\author{
L G SVIRKLYS, ${ }^{*}$ B WILCKEN, $†$ J HAMMOND,$\dagger$ A G MACKINLAY,${ }^{*}$ AND W J O’SULLIVAN*
}

${ }^{*}$ School of Biochemistry, University of New South Wales, and +Oliver Latham Laboratories, Macquarie Hospital, New South Wales, Australia

SUMMARY Six families with at least one infant each with confirmed ornithine transcarbamylase deficiency were investigated by DNA analysis. All the affected sons had died, and no DNA had been stored. Using the restriction endonucleases MspI and Bam HI three restriction fragment length polymorphisms were detected which led to eight distinct haplotypes. Using these results and those of protein loading tests that diagnosed heterozygote (carrier) status in some family members, some carriers were detected, and prenatal diagnosis was offered to two families. In two further families no polymorphisms were found and no prenatal diagnosis was possible. In the remaining two families prenatal diagnosis was impossible because of the lack of DNA from an affected or unaffected son, or in one case from the father, of an obligate carrier.

These studies emphasise the importance of preserving tissue for DNA extraction from infants dying of inborn errors of metabolism, and also show the way in which information from conventional biochemical studies can complement diagnostic tests using DNA.

Deficiency of ornithine transcarbamylase (Enzyme Commission No 2.1.3.3), an enzyme in the urea cycle, is a severe $\mathrm{X}$-linked disorder which results in hyperammonaemia and early death in affected hemizygote male infants. ${ }^{1-3}$ Due to random inactivation of $\mathrm{X}$ chromosomes female carriers have variable amounts of enzyme activity and a less severe form of the deficiency. This may show itself in protein intolerance, cyclical vomiting, and mental retardation, although many carriers are asymptomatic.

Ornithine transcarbamylase is a mitochondrial enzyme expressed only in liver and small intestinal mucosa, ${ }^{1}$ so prenatal diagnosis by chorionic villus sampling or amniocentesis is not possible. Detection of carriers has been attempted by giving an orotic acid free protein load and measuring urinary excretion of orotic acid and blood ammonia concentrations. Though a positive result can successfully indicate a carrier a negative result does not necessarily indicate normality because of the variability of enzyme activity that may approach normal in some carriers. ${ }^{1}$ For example, an asymptomatic woman whose daughter and two infant sons died from ornithine transcarbamylase deficiency had normal protein loading tests. ${ }^{4}$

Isolation of the gene for ornithine transcarbamy- lase has permitted an alternative approach to the diagnosis of the disorder by DNA analysis. ${ }^{5}$ Although the mutations responsible for the deficiency are unknown, in most circumstances the disorder can be detected by establishing linkage between the mutant gene and a restriction fragment length polymorphism within or near the gene locus. ${ }^{6-8}$ Once a restriction fragment length polymorphism has been closely linked to a particular gene, it may be possible to track that gene by its restriction fragment length polymorphism, which will be transmitted along Mendelian lines within a family. In this study we describe our experience using DNA linkage analysis for the detection of carriers and in prenatal diagnosis of six kindred at risk of ornithine transcarbamylase deficiency.

\section{Patients and methods}

Members of six kindred with ornithine transcarbamylase deficiency were studied. Figs 1a-f show the pedigrees of these families.

KINDRED A (fig 1a)

Ornithine transcarbamylase deficiency was diagnosed after the propositus (III 5) presented when 2 days old with hyperammonaemic coma and died 

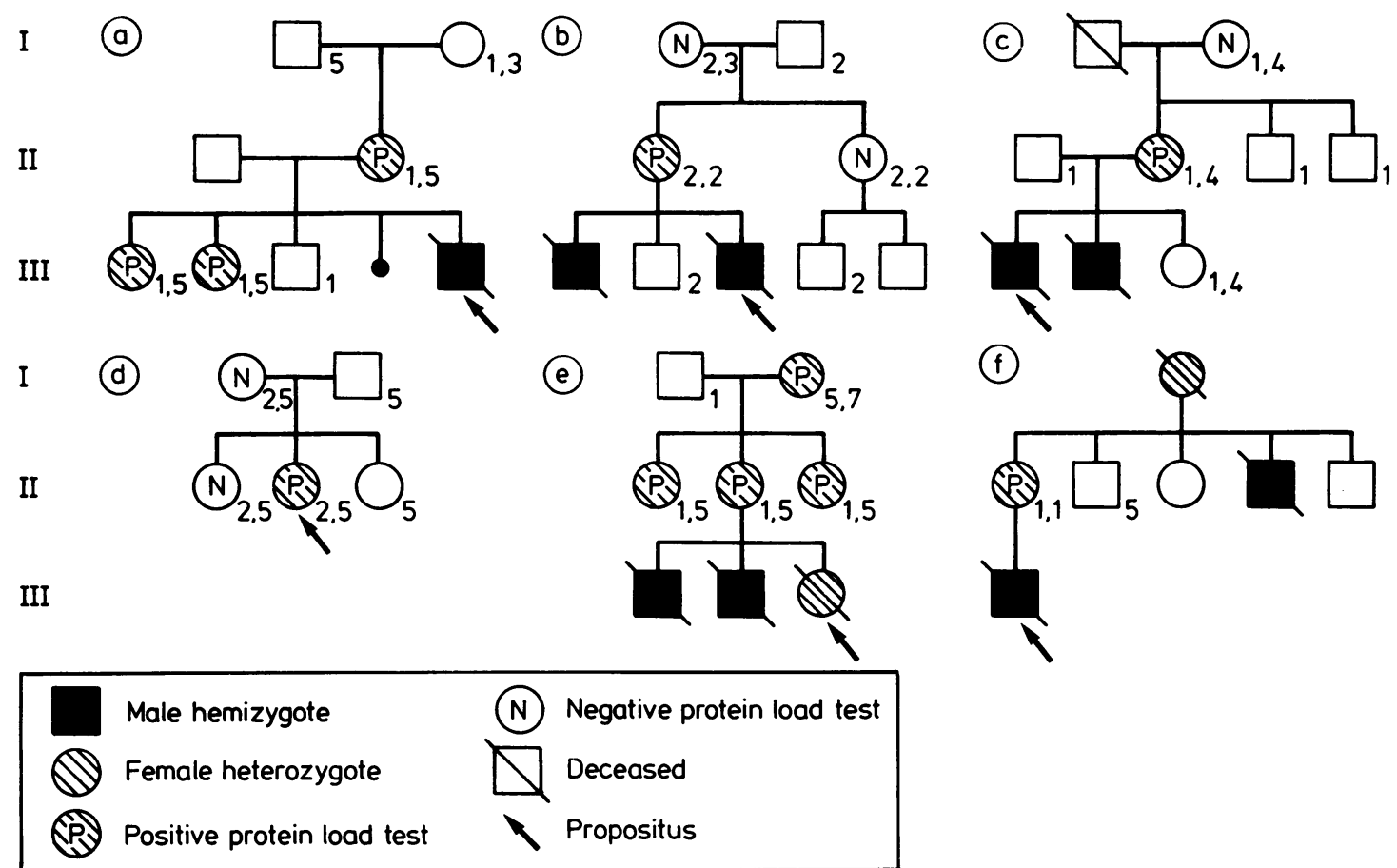

Fig 1a-f Pedigrees of kindreds A-F. Roman numerals indicate generations, Arabic numerals indicate haplotypes.

on day 4. Analysis of liver obtained by needle biopsy before death showed barely detectable ornithine transcarbamylase activity; other enzymes of the urea cycle were within the normal ranges. His mother (II 2) and two sisters (III 1 and III 2) had unequivocally positive results when given a formal protein loading test. ${ }^{9}$

KINDRED B (fig lb)

The propositus (III 3 ) died when 4 days old, having become hyperammonaemic on day 2 . Ornithine transcarbamylase deficiency was suspected when analysis of the urine showed high concentrations of orotic acid, and plasma citrulline concentration was undetectable. The diagnosis was confirmed when ornithine transcarbamylase activity was found to be less than $10 \%$ of normal in liver obtained before death by needle biopsy. An earlier male sibling had died in identical circumstances, and the mother (II 1) was therefore diagnosed as an obligate heterozygote for ornithine transcarbamylase deficiency. Her protein loading tests were positive but those of her sister (II 2) and their mother (I 1) were negative.

KINDRED C (fig 1c)

The propositus (III 1) died in the neonatal period and a diagnosis of ornithine transcarbamylase de- ficiency was suggested by analysis of blood and urine; this was confirmed by assay of liver enzyme activity. A second son (III 2) was treated for ornithine transcarbamylase deficiency from birth. This had been diagnosed by a low plasma citrulline concentration together with increased excretion of orotic acid in the urine. He was never hyperammonaemic and had remained well on treatment for eight months, when he died suddenly during an intercurrent infection. The mother (II 2) was thus an obligate heterozygote. Her mother (I 2) had a normal protein loading test.

\section{KINDRED D (fig 1d)}

The propositus (II 2), a girl of 3 years old, was found to be a carrier for ornithine transcarbamylase deficiency after she presented with protein intolerance and cyclical vomiting. The diagnosis was suspected when raised concentrations of blood ammonia together with increased excretion of orotic acid in the urine were found. A liver biopsy specimen showed ornithine transcarbamylase concentrations of about $30 \%$ of normal. Neither her mother (I 1) nor her sister (II 1) showed any evidence of ornithine transcarbamylase deficiency and in both the protein loading tests were negative. 
KINDRED E (fig le)

In this family the propositus was a girl aged 18 months who presented with recurrent vomiting. She had increased excretion of orotic acid in the urine, a raised blood ammonia concentration, and raised plasma glutamine concentration; no other plasma amino acids were appreciably raised. She died of an ependymoblastoma at the age of $2 \frac{1 / 2}{\text { years. }}{ }^{10}$ Her mother (II 2) had had two sons both of whom died in the first week of life. Protein loading tests on the mother, her two sisters and their mother gave unequivocally positive results.

KINDRED F (fig 1f)

The mother (II 1) was diagnosed as a heterozygote for ornithine transcarbamylase deficiency on her family history and the positive results of a protein loading test. The propositus, her son, died when 3 days old following the onset of vomiting and coma on day 2. Excretion of orotic acid in the urine was raised and the plasma citrulline concentration was undetectable. A sample of liver obtained by needle biopsy showed complete absence of cross reacting ornithine transcarbamylase protein. The mother's brother (II 4) had died aged 5 days of unknown cause.

\section{DNA ANALYSIS}

DNA was prepared by standard methods from the buffy coat fraction obtained from $10 \mathrm{ml}$ of blood. ${ }^{11}$ DNA $(10 \mu \mathrm{g})$ was digested with restriction endonucleases MspI, Bam HI, or Taq I (Pharmacia) under conditions recommended by the supplier. The resulting restriction fragments were separated by agarose gel electrophoresis $(0 \cdot 8 \%$ agarose, $16-18$ hours at $1.8 \mathrm{~V} / \mathrm{cm})$ in Tris-acetate-EDTA buffer. $^{12}$ DNA transfer to nitrocellulose membranes, prehybridisation, and hybridisation were carried out by the methods described by Maniatis et $a l,{ }^{12}$ with hybridisation in the presence of $50 \%$ formamide for 18 hours at $42^{\circ}$. The radioactive hybridisation probe was prepared by labelling a recombinant plasmid containing a full length of complementary DNA for human ornithine transcarbamylase $^{5}$ to give a specific radioactivity of at least $10^{8} \mathrm{dpm} / \mu \mathrm{g}$. After hybridisation the filters were washed for one hour at room temperature in $2 \times$ $\mathrm{SSC}(\mathrm{SSC}=0 \cdot 15 \mathrm{M}$ sodium chloride, $0 \cdot 015 \mathrm{M}$ sodium citrate, $\mathrm{pH}=7 \cdot 0)$, and then three times for 30 minutes each in $0 \cdot 1 \times \mathrm{SSC}$ at $65^{\circ}$. Bands were detected by auto-radiography at $-70^{\circ}$ using preflashed Fuji RX $x$ ray film. Fragment sizes were measured by reference to Hin dIII-digested $\lambda$ phage DNA.

PROTEIN LOADING TEST

After an overnight fast patients were given a protein load of $1 \mathrm{~g} / \mathrm{kg}$ body weight derived from steamed chicken breast. Fasting and 0 to six hours after the load urinary orotic acid concentrations were compared with those from age matched controls." Urinary orotic acid was measured by the method of Harris and Oberholzer. ${ }^{13}$

\section{Results}

The restriction endonuclease $M s p I$ detected two separate restriction fragment length polymorphisms, the alleles measuring 6.6 and $6.2 \mathrm{~kb}$ pairs in one case and measuring $5 \cdot 1$ and $4.4 \mathrm{~kb}$ pairs in the other;

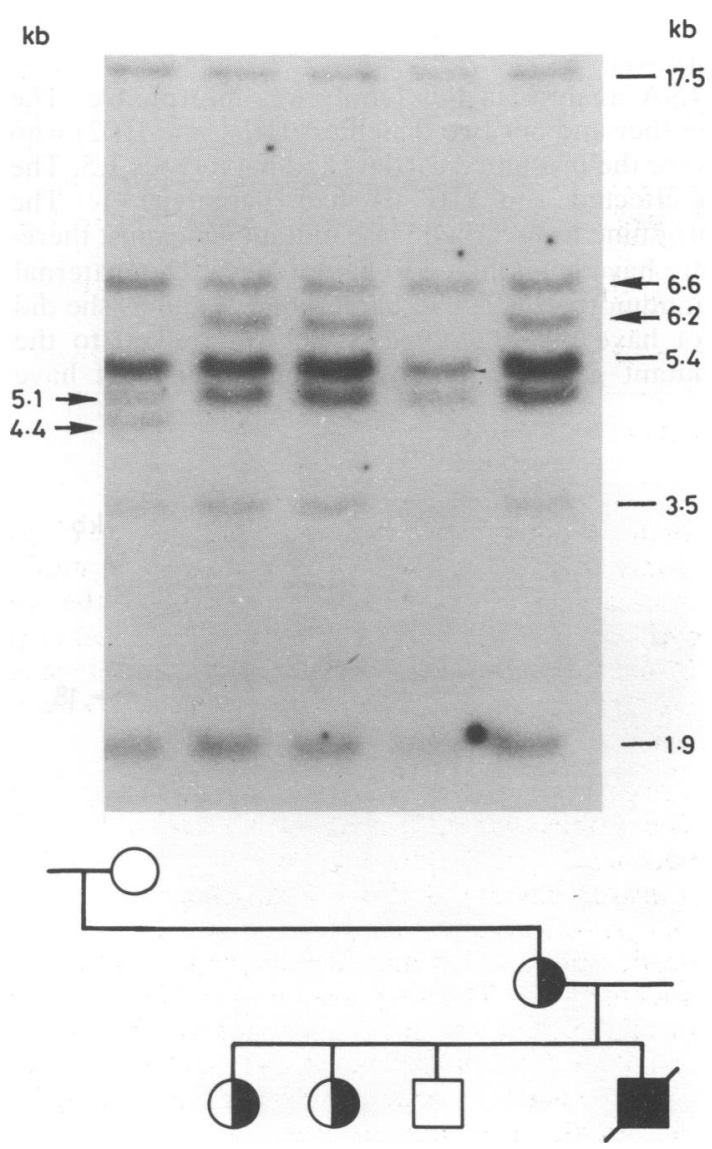

Fig 2 Partial pedigree and Southern blot analysis of family A with MspI digested DNA hybridised with OTC $c D N A$. Band sizes are given in kb (kilobase pairs). Polymorphic sites are illustrated by arrows. The proband is shown as $\mathbf{\square}$, carrier females as $\mathbf{0}$, normal female $\bigcirc$, normal male $\square$. Each lane in the Southern blot is labelled with the pedigree designation of the family member whose DNA was analysed in that lane. 
Bam HI gave a single restriction fragment length polymorphism comprising 18 and $5.2 \mathrm{~kb}$ bands (figs 2 and 3 ). As a result any $X$ chromosome may have one of eight possible haplotypes-that is, combinations of the three pairs of alleles. The table shows haplotypes $1-8$.

Haplotype construction was facilitated by analysis of restriction fragment length polymorphisms of an appropriate male subject from each family in whom the presence of a single $X$ chromosome allowed the haplotype to be specified in all cases. Thus for females, it was always possible to deduce which restriction fragment length polymorphisms were linked to one another on the two separate $\mathrm{X}$ chromosomes.

\section{KINDRED A}

DNA analysis in this family was informative. The mother and her two daughters (III 1 and III 2) who were the presumed carriers had haplotypes 1,5 . The unaffected son (III 3) had haplotype 1. The ornithine transcarbamylase mutant gene must therefore have been linked to haplotype 5 . The maternal grandmother (I 2) had haplotype 1,3 and as she did not have the haplotype 5 that was linked to the mutant gene a spontaneous mutation must have

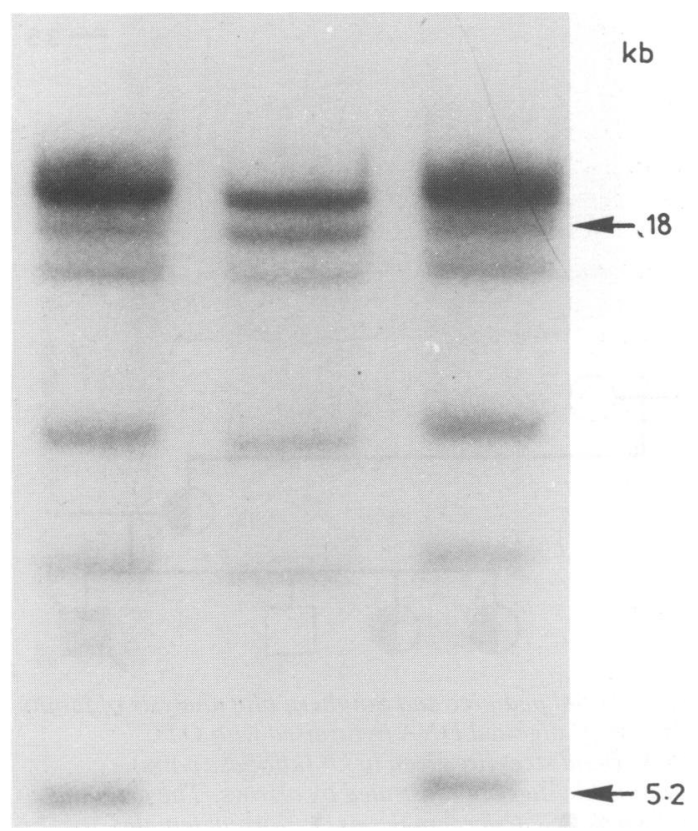

Fig 3 Southern blot analysis of Bam HI digested DNA hybridized with OTC $c D N A$. Band sizes are given in $K b$. Polymorphic sites are illustrated by arrows.
Table Assignment of haplotypes for restriction fragment length polymorphisms about the ornithine transcarbamylase gene

\begin{tabular}{|c|c|c|}
\hline \multirow[t]{2}{*}{ Haplotype } & \multicolumn{2}{|c|}{ Restriction endonucleases } \\
\hline & $\operatorname{Mspl}(k b)^{*}$ & Bam $H I(k b)$ \\
\hline 1 & $6 \cdot 6 \quad 5 \cdot 1$ & 18 \\
\hline 2 & $6 \cdot 6 \quad 5 \cdot 1$ & $5 \cdot 2$ \\
\hline 3 & $6 \cdot 6 \quad 4 \cdot 4$ & 18 \\
\hline 4 & $6 \cdot 6 \quad 4 \cdot 4$ & $5 \cdot 2$ \\
\hline 5 & $6 \cdot 2 \quad 5 \cdot 1$ & 18 \\
\hline 6 & $6 \cdot 2 \quad 5 \cdot 1$ & $5 \cdot 2$ \\
\hline 7 & $6 \cdot 2 \quad 4 \cdot 4$ & 18 \\
\hline 8 & $6 \cdot 2 \quad 4 \cdot 4$ & $5 \cdot 2$ \\
\hline
\end{tabular}

${ }^{*} M s p$ I detected two restriction fragment length polymorphisms.

occurred in either a germ cell from the maternal grandfather or in an early cleavage, and II 2 thus carried a new mutation. The maternal grandmother and her four sisters (not shown) could therefore be assured that they were not carriers.

\section{KINDRED B}

The propositus's mother (II 1) was the only known carrier in this kindred. Her haplotype was 2,2 and as we detected no restriction fragment length polymorphism about the ornithine transcarbamylase gene, prenatal diagnosis could not be offered to her. Her mother (I 1) had haplotype 2,3 and her father (I 2 ) had haplotype 2 . The maternal grandmother of the propositus (I 1) and maternal aunt (II 2) had negative protein loading tests so that it was not certain whether this was a new mutation. If I 1 were a carrier, the maternal aunt with haplotype 2,2 would also be a carrier. II 2's affected X chromosome, however, could also have been derived from a new mutation in a germ cell from either her mother or her father, or from a mutation in an early cleavage.

\section{KINDRED C}

The mother of the propositus (II 2) had haplotype 1,4 , her mother had haplotype 1,4 and her two brothers II 3 and II 4 and her husband had haplotype 1 . Her newly born daughter III 3 had haplotype 1,4 . As the propositus's maternal grandmother had a negative protein loading test it was uncertain whether she was a carrier. In this case prenatal diagnosis could have been offered to II 2 if DNA had been available from one of the affected sons (III 1 or III 2). Should the newborn daughter III 3 be confirmed to be a carrier by a loading test, however, then the defective gene would probably segregate with haplotype 4 , because III 3 obtained 
her haplotype 1 from her (unaffected) father. In this eventuality diagnosis could have been offered.

\section{KINDRED D}

The only known heterozygote for ornithine transcarbamylase deficiency in this family, II 2 , had haplotype 2,5. Her mother and sister also had these haplotypes and her father and her unaffected brother had haplotype 5. Protein loading tests in both the mother and the sister were negative. Thus it was not certain whether the propositus's carrier state was the result of a new mutation or whether her mother and sister were also carriers. Had her sister inherited haplotype 5 from her mother instead of haplotype 2 , then heterozygosity could confidently have been excluded. The information obtained, however, made it certain that as far as ornithine transcarbamylase was concerned her genotype was the same as her mother's. Either both were carriers or both were normal, and this affected genetic counselling about risk rates.

\section{KINDRED E}

The propositus's mother (II 2) was a carrier for ornithine transcarbamylase deficiency as she had given birth to two sons with presumed ornithine transcarbamylase deficiency and had a positive protein loading test. DNA analysis showed that she and her two sisters had haplotypes 1,5, her mother had haplotype 5,7, and her father had haplotype 1 . As all three sisters and their mother had had positive protein loading tests all were presumed to be carriers. The defective gene in this family was linked to haplotype 5 , because the sisters' father, who was healthy, had haplotype 1 . Thus prenatal diagnosis could be offered to all three sisters.

\section{KINDRED F}

II 1 had haplotype 1,1 and thus it was not possible to distinguish between her two $\mathrm{X}$ chromosomes using only MspI and Bam HI. No prenatal diagnosis was possible for her at the time of writing.

A change of a $T a q$ I restriction endonuclease site in two families with ornithine transcarbamylase deficiency was recently described, which could represent a new mutation or another polymorphism. ${ }^{8}$ Because the restriction fragment length polymorphisms for MspI and Bam HI were uninformative in two kindreds (B and $\mathrm{F}$ ) we investigated two carriers (kindred B (II 2) and kindred F (II 2)) for the presence of these Taq I sites; no changes were found. Further, no change in the Taq I sites in carriers from two other families (kindred A (II 2) and kindred C (II 2)) were found. In addition, a Taq I polymorphism characterised by a 3.7 and $3.6 \mathrm{~kb}$ band has been described. ${ }^{14}$ We have had no success in finding this restriction fragment length polymorphism in carriers from four kindred with the deficiency $(\mathrm{A}, \mathrm{B}, \mathrm{C}$, and $\mathrm{F})$ nor in 20 control female subjects.

\section{Discussion}

In this paper we describe the investigation of six kindreds of patients with ornithine transcarbamylase deficiency using a cDNA probe for the ornithine transcarbamylase gene, and illustrate the principles and problems of this type of analysis.

Before the availability of cDNA probes prenatal diagnosis of ornithine transcarbamylase deficiency could only be attempted by diagnosing sex and then terminating pregnancies with a male fetus $(50 \%$ of which would probably be unaffected), ${ }^{1}$ or by examination of a fetal liver biopsy specimen, ${ }^{15}$ which is not always possible. Prenatal diagnosis by direct gene analysis was first achieved by Old et al, who excluded ornithine transcarbamylase deficiency in a male fetus from a family in which karyotyping had established the presence of a deletion. ${ }^{7}$

Where there are no deletions, the disorder can be detected by establishing a linkage between the mutant ornithine transcarbamylase gene and restriction fragment length polymorphisms in or around the gene. Rozen et al reported that a combination of restriction fragment length polymorphisms observed with Bam HI and MspI could be expected to be informative for $80 \%$ of women at risk. ${ }^{6}$

For linkage studies to be helpful for prenatal diagnosis of an X-linked disorder such as ornithine transcarbamylase deficiency, there are certain prerequisites. Firstly, the mother must be a known carrier of an ornithine transcarbamylase mutation and a heterozygote for a restriction fragment length polymorphism. Secondly, there must be either DNA available from at least one son, affected or unaffected, or the mother's mother must be a known carrier, and DNA must be available from the mother's father or a brother. A known carrier of an ornithine transcarbamylase mutation is defined as either an obligate carrier on family history or a subject shown to be a carrier by the results of a carefully controlled protein loading test. When all this information is not available it may be possible to make an exclusion diagnosis in a proportion of cases, but prenatal diagnosis cannot unequivocally be offered.

In the kindreds we studied DNA was not available from any of the affected deceased sons. In kindreds $A$ and $E$ information from a combination of both the DNA and protein loading studies made prenatal diagnosis available for the mothers of affected sons 
as well as for two daughters in kindred $\mathrm{A}$ and two sisters in kindred $\mathrm{E}$. The information from protein loading tests enabled these family members to be classified as carriers, and the DNA study showed that the $\mathrm{X}$ chromosome could be successfully tracked. This was possible in kindred $\mathrm{E}$ because DNA was available from the father of the three sisters, and their mother was known to be a carrier from a protein loading study.

In the other four kindreds prenatal diagnosis could not be offered to the mothers of affected boys, either because they were not heterozygous for any detected restriction fragment length polymorphism (kindreds B and F) or because DNA from affected or unaffected sons was unavailable, in addition to the uncertainty about whether these mothers were carriers as a result of a new mutation. Nevertheless, diagnosis by exclusion might have been possible in some of these families if their haplotypes had been different as illustrated by the results for kindred D, but in no case was this so.

The current study indicates two important points. Firstly, DNA diagnostic tests may be successfully complemented by conventional biochemical techniques. Another example is the use of creatine kinase measurements in defining carrier states in Duchenne type and Becker's muscular dystrophy. ${ }^{16}$ Secondly, it is vital that tissue or DNA itself should be collected and stored from any patient with an inherited disorder who seems likely to die. It is crucial that paediatric and obstetric units obtain a protocol from their regional molecular biology service so that such collections can be made at any time.

We thank Dr N Hoogenraad, Biochemistry Department, La Trobe University, for carrying out the ornithine transcarbamylase assays and Ms Mary Potter, Oliver Latham Laboratories, for performing the protein loading tests. We also thank Dr Leon Rosenberg for providing us with the cDNA probe, and $\mathrm{Dr} \mathrm{KE}$ Davies for confirming the studies on kindred F. This study was made possible by a grant from the Clive and Vera Ramaciotti Foundations.

\footnotetext{
References

1 Walser M. Urea cycle disorders and other hereditary hyperammonemic syndromes. In: Stanbury JB, Wyngaarden JB,
} Frederickson DS, Goldstein JL, Brown MS, eds. The metabolic basis of inherited disease. New York: McGraw Hill, 1983: 402-38.

2 Short EM, Conn HO, Snodgrass PG, Campbell AGM, Rosenberg LE. Evidence of X-linked dominant inheritance for ornithine transcarbamylase deficiency. N Engl J Med 1973;288: $7-12$.

${ }^{3}$ Ricciuti FC, Gelehrter TD, Rosenberg LE. X chromosome inactivation in human liver; confirmation of X-linkage of ornithine transcarbamylase. Am J Hum Genet 1976;28:332-8.

4 Becroft DM, Barry DM, Webster DR, Simmonds HA. Failure of protein loading tests to identify heterozygosity for ornithine carbamyltransferase deficiency. J Inherited Metab Dis 1984;7: 157-9.

5 Horwich AL, Fenton WA, Williams KR, et al. Structure and expression of a complementary DNA for nuclear coded precursor of human mitochondrial ornithine transcarbamylasc. Science 1984;224:1068-74.

${ }^{6}$ Rozen R, Fox J, Fenton WA, Harewich AL, Rosenberg LE. Gene deletion and restriction fragment length polymorphisms at the human ornithine transcarbamylase locus. Nature 1985;313: 815-7.

7 Old JM, Briand PL, Purvis-Smith S, et al. Prenatal exclusion of ornithine transcarbamylase deficiency by direct gene analysis. Lancet 1985;i:73-5.

${ }^{`}$ Nussbaum RL, Boggs BA, Beaudet AL, Doyle S, Potter JL, O'Brien WE. New mutation and prenatal diagnosis in ornithine transcarbamylase deficiency. Am J Hum Genet 1986;38:149-58.

${ }^{9}$ Potter M, Hammond J, Wilcken B. Establishing heterozygosity for ornithine transcarbamylase deficiency. Aust Paediatr $J$ 1987;23:67.

11 Lipson A, Bale P. Ependymoblastoma associated with prenatal exposure to diphenylhydantoin and methyl phenobarbitone. Cancer 1985;55:1859-62.

1 Old JM, Higgs DR. Gene analysis. In: Weatherall DJ, ed. Methods and haematology - the thalassemias. Vol 6. Edinburgh: Churchill Livingstone, 1983:74-102.

12 Maniatis T, Fritsch EF, Sambrook J. Molecular cloning: a laboratory manual. Cold Spring Harbor: Cold Spring Harbor Laboratory, 1982.

${ }^{13}$ Harris ML, Oberholzer VG. Conditions affecting the colorimetry of orotic acid and orotidine in urine. Clin Chem 1980;26:473-9.

${ }^{14}$ Fox JE, Hack AM, Fenton WA, Rosenberg LE. Identification and application of additional restriction fragment length polymorphisms at the human ornithine transcarbamylase locus. $\mathrm{Am}$ J Hum Genet 1986;38:841-7.

is Rodeck CH, Patrick AD, Pembrey ME, Tzannatos C, Whitfield AE. Fetal liver biopsy for prenatal diagnosis of ornithine carbamyl transferase deficiency. Lancet 1982;ii:297-300.

16 Kingston HM, Sarfarazi M, Newcombe RC, Willis N, Harper PS. Carrier detection in Becker muscular dystrophy using creatine kinase estimation and DNA analysis. Clin Gene 1985;27:283-91.

Correspondence to Dr B Wilcken, Oliver Latham Laboratorics, Macquaire Hospital, North Ryde, NSW 2113, Australia.

Received 6 August 1987 